\title{
Responses to the Pilot Systematic Review of Problem- based Learning
}

Citation for published version (APA):

Newman, M., van den Bossche, P. G. C., Gijbels, D., McKendree, J., Roberts, T., \& Rolfe, I. (2004).

Responses to the Pilot Systematic Review of Problem-based Learning. Medical Education, 38, 921-923. https://doi.org/10.1111/j.1365-2929.2004.01943.x

Document status and date:

Published: 01/01/2004

DOI:

10.1111/j.1365-2929.2004.01943.x

Document Version:

Publisher's PDF, also known as Version of record

\section{Please check the document version of this publication:}

- A submitted manuscript is the version of the article upon submission and before peer-review. There can be important differences between the submitted version and the official published version of record.

People interested in the research are advised to contact the author for the final version of the publication, or visit the DOI to the publisher's website.

- The final author version and the galley proof are versions of the publication after peer review.

- The final published version features the final layout of the paper including the volume, issue and page numbers.

Link to publication

\footnotetext{
General rights rights.

- You may freely distribute the URL identifying the publication in the public portal. please follow below link for the End User Agreement:

www.umlib.nl/taverne-license

Take down policy

If you believe that this document breaches copyright please contact us at:

repository@maastrichtuniversity.nl

providing details and we will investigate your claim.
}

Copyright and moral rights for the publications made accessible in the public portal are retained by the authors and/or other copyright owners and it is a condition of accessing publications that users recognise and abide by the legal requirements associated with these

- Users may download and print one copy of any publication from the public portal for the purpose of private study or research.

- You may not further distribute the material or use it for any profit-making activity or commercial gain

If the publication is distributed under the terms of Article $25 \mathrm{fa}$ of the Dutch Copyright Act, indicated by the "Taverne" license above, 


\section{commentaries}

\section{Responses to the pilot systematic review of problem-based learning}

Mark Newman, Piet Van den Bossche, David Gijbels, Jean McKendree, Tony Roberts, Isobel Rolfe, John Smucny E゚ Giovanni De Virgilio (Campbell Collaboration Review Group on the Effectiveness of Problem-based Learning)

We would like to thank Diana Dolmans, ${ }^{1}$ Richard Farrow, and Geoff Norman ${ }^{2}$ for taking the time to read and comment on the report of the pilot systematic review and metaanalysis we completed. ${ }^{3}$ Such responses are an indication that the report has been successful in at least 2 of its goals: it has stimulated further debate about the effectiveness of problem-based learning (PBL) and how it should be evaluated, and it has encouraged the improvement of studies aimed at answering this question. We would find it difficult to disagree with many of the points made by the authors of these commentaries, given that we made many of them ourselves in the report. We would like to encourage readers to view the report for themselves on the LTSN-01 (Learning and Teaching Subject Network for Medicine, Dentistry and Veterinary Medicine) website at http:/ / www. ltsn-01.ac.uk/resources/features/pbl.

The report has been successful in a least 2 of its goals: it has stimulated further debate about the effectiveness of problem-based learning and how it should be evaluated, and has encouraged the improvement of studies aimed at answering this question

Correspondence: Mark Newman, Evidence for Policy and Practice Information and Coordinating Centre, Social Science Research Unit, Institute of Education, University of London, 18 Woburn Square, London, WC1H ONR, UK. Tel: 00442076126575 ;

Fax: 0044207 6126400;

E-mail: m.newman@ioe.ac.uk.

doi: 10.1111/j.1365-2929.2004.01943.x
It is perhaps useful to state the review group's primary objective for this pilot study. This is: 'To establish the evidence provided by existing published reviews about the effectiveness of PBL... when compared to other non-PBL teaching and learning strategies.' The above respondents suggest that such a question is invalid. We must disagree. As teachers and curriculum developers using approaches that have been labelled PBL, we are concerned with this question, as are our colleagues and our students. We want to know what actions, values, behaviours, roles and environments we should adopt in order to maximise the success of our students. In our view, it is disingenuous of those who carry out research in this field or advocate the adoption of PBL curricula to pretend that the question of the relative benefits of different approaches is not a valid concern. In fact, the authors have made such arguments themselves. Dolmans and Schmidt, for example, argue that PBL helps students develop richer mental models. ${ }^{4}$ The claim itself is indicative of a comparison: 'richer' than what or when? The report thus had a particular goal in mind and chose a methodology appropriate to answering that question. This in no way implies a rejection of other methods, nor does it imply a rejection of student-centred or 'constructivist' approaches to teaching or research. The 'constructivism' referred by Diana Dolmans should best be viewed as an umbrella term covering a range of theoretical approaches and as such does not predict any particular method of teaching and/or research method as most appropriate. ${ }^{5}$

We want to know what actions, values, behaviours, roles and environments we should adopt to maximise the success of our students

The focus on experimental and quasi-experimental research designs in our review does not imply that other research approaches are less valuable or important. Qualitative studies are required to help us understand the teaching and learning that occur in the different approaches to PBL and thus are invaluable. But by themselves these studies do not tell us whether the adoption of PBL will lead to the intended learning outcomes more effectively than alternative approaches. Such claims of greater effectiveness are precisely what the systematic review methodology is designed to evaluate.

Qualitative studies are required to help us understand the teaching and learning that occur in the different approaches to PBL and thus are invaluable

Our review methodology borrowed heavily from the Cochrane Group on the Effectiveness of Practice and 
Organisation of Care (EPOC). Using this approach, EPOC has, in our view, provided much high quality evidence about instructional interventions; it has, for instance, clearly identified continuing education approaches that are ineffective at improving clinical practice. ${ }^{6}$ Inclusion in the review did require that PBL be compared to another approach, whether 'traditional' or not. This means of selecting studies is based on theoretical and empirical evidence that well designed, properly conducted, randomised experimental designs are optimal for the demonstration of 'cause and effect' and for the minimisation of bias in evaluating effectiveness. ${ }^{7-9}$ We are not convinced of the claim that the complexity of education is greater than that of any other area of social science, nor, apparently, are a great many other educational researchers. ${ }^{10}$ Indeed, we would argue that the complexity of educational interventions supports the use of randomised experimental designs rather than dictating against them when evaluating claims of effectiveness.

However, qualitative studies do not tell us whether the adoption of PBL will lead to the intended learning outcomes more effectively than alternative approaches

As for Farrow and Norman's point ${ }^{2}$ that the outcome measures were not the best for evaluating PBL, we do not necessarily disagree. In principle, any outcome measures reported could have been included in the review, provided that the reliability of the instrument or the method used to 'assess' the programme was reported and follow-up was sufficiently inclusive. The issues of measurement are linked to, but are not the same as, study design. The claim that PBL could be demon- strated as being more effective if different outcome measures were used requires empirical testing. Just what outcomes and instruments are appropriate is a matter for debate for all of us in the research community. Our report did not discuss this issue in detail as a systematic review is by definition a review of existing literature that uses the measures reported by the studies in the literature.

$$
\begin{gathered}
\text { Just what outcomes and instruments } \\
\text { are appropriate is a matter for } \\
\text { debate for all of us in the research } \\
\text { community }
\end{gathered}
$$

Our report also pointed out many serious methodological and practical issues concerned with the process of conducting such reviews, including the problems of analysis and synthesis, whether narrative or statistical, and highlighted in particular the problems associated with the inadequate specification of 'PBL' and/or the approach to which it is compared. However, such matters can only be resolved through collaboration in the design and conduct of high quality primary and secondary research to address these issues. We would like to invite Diana, Richard, Geoff and any other colleagues to join us in continuing to review and synthesise work in this field.

\section{The claim that PBL could be dem- onstrated as being more effective if different outcome measures were used requires empirical testing}

We would also like to clarify that the research upon which the report was based was funded by the UK Economic and Social Research Council's Teaching and Learning Research Programme and the review group members' own institutions. The Learning and Teaching Subject Network Centre for Medicine, Dentistry and Veterinary Medicine (LTSN-01) gave a small amount of funding for literature searching and published the pilot report and we are grateful to it for doing so. Although we have made contact with Best Evidence in Medical Education (BEME), this review was not completed under the auspices of BEME and the methods used in our review cannot be assumed to indicate anything about BEME's intentions.

\section{REFERENCES}

1 Dolmans D. The effectiveness of PBL: the debate continues. Some concerns about the BEME movement. Med Educ 2003;37: 1129-30.

2 Farrow R, Norman GR. The effectiveness of PBL: the debate continues. Is meta-analysis helpful? Med Educ 2003;37:1131-2.

3 Newman M \& the Pilot Review Group. A Pilot Systematic Review and Meta-analysis on the Effectiveness of Problem-based Learning. Newcastle: Learning and Teaching Subject Network for Medicine, Dentistry and Veterinary Medicine 2003. http://www.ltsn-01.ac.uk/ resources/features/pbl.

4 Dolmans D, Schmidt H. What directs self-directed learning in a problem-based curriculum. In: Evenson D, Hmelo C, eds. Problembased Learning: a Research Perspective on Learning Interactions. Mahwah, New Jersey: Lawrence Earlbaum Associates 2000;251-62.

5 Tynjälä P. Towards expert knowledge: a comparison between constructivist and a traditional learning environment in the university setting. Int J Educational Res 1999;31:357-442.

6 Davis DA, Thomson O'Brien MA, Freemantle N, Wolf F, Mazmanian $\mathrm{P}$, Taylor-Vaizey A. Impact of formal continuing medical education: do conferences, workshops, rounds and other traditional 
continuing education activities change physician behaviour or health care outcomes? JAMA 1999;282 (9):867-74.

7 Boruch RF. Randomised Experiments for Planning and Evaluation. Thousand Oaks, California: Sage Publications 1997.
8 Shultz K, Chalmers I, Hayes R, Altman D. Empirical evidence of bias: dimensions of methodological quality associated with estimates of treatment effects in controlled trials. JAMA 1995;273:408-12.
9 Cook TD, Campbell DT. QuasiExperimentation: Design and Analysis Issues in Field Settings. Chicago: Rand McNally 1979.

10 National Research Council. Scientific Research in Education. Washington DC: National Academy Press 2002.

\title{
Problem-based learning: the confusion continues
}

\author{
Barbara Miflin
}

The comments in this brief review were inspired by Gilkison's ${ }^{1}$ report on her search for greater clarity in regard to the appropriate qualifications of problem-based learning (PBL) tutors in undergraduate medical curricula. The study Gilkison conducted was well considered and well reported. Despite the best intentions of the researcher, however, the study's results serve to add to rather than diminish the confusion about PBL and the tutor's role. As I have argued before in this forum, ${ }^{2}$ further research in PBL curricula will be fruitless until the confusion in thinking about PBL itself is addressed.

Further research in PBL curricula will be fruitless until the confusion in thinking about PBL itself is addressed

Gilkison cites Barrows' view that the ideal PBL tutor is a group facilitator rather than a subject matter expert. However, what she overlooks in Barrows' recommendations is that

Correspondence: Associate Professor Barbara Miflin, Medical Education Support Unit, School of Medicine, University of Notre Dame

Australia, 5 Mouat Street, Fremantle, West Australia 6160, Australia.

Tel: 006189433 0233;

Fax: 0061894330210 ;

E-mail: bmiflin@nd.edu.au.

doi: $10.1111 /$ j.1365-2929.2004.01920.x he was talking about the different qualities in tutors who are doctors. Barrows promulgated the concept of PBL in the context of medical education as it was traditionally organised in the USA and Canada, Barrows' home environment. Traditionally in this environment, medical schools provided a clinical phase of learning after students had completed a premedical, sciencebased course, often in a different institution. Doctors taught medical students in graduate medical schools. Barrows intended that this phase of medical education would adopt PBL for the first 2 of 4 years, primarily to ensure that students were given time and the help of a PBL tutor to understand the relevance to making competent clinical decisions of the science they had already learnt in isolation.

The concept of 'expertise' for Barrows related to expertise in medical disciplines

I can understand how Barrows' intention may have been missed or misconstrued. In my extensive critique of Barrows' teachings on $\mathrm{PBL},{ }^{3}$ I did not once find any overt reference to PBL tutors having to be medically qualified. Critical interpretation of his ideas, however, in the context in which they were formed (as described above), leads inevitably to this conclusion. I suspect that Barrows did not spell it out because he assumed that it would be taken for granted.

In the context that Barrows intended, the concept of 'expertise' was of expertise in medical disciplines. Barrows meant that a doctor who is a good facilitator, is, regardless of his or her medical discipline ('nonexpert'), a better PBL tutor in, for example, a renal 'problem', than a doctor who is a renal physician ('expert') but a poor facilitator. In contrast, Gilkison compares a doctor and a tutor with a humanities qualification as PBL tutors. If my argument is accepted, the comparison is fundamentally flawed, and thus, the results are unhelpful. It may also explain why the author seemed to be in 2 minds about which was superior after observing the advantages to student learning under the guidance of both types of teachers. From the perspective of Barrows' original idea, the 2 should be combined. He envisaged that the PBL-trained clinician would combine medical know-how with good facilitation skills. The result would be an active teaching role with tutor intervention being used optimally to develop students' abilities to synthesise and apply knowledge to clinical problems. By the end of what he called 'the 